\title{
Photoautotrophic picoplankton - a review on their occurrence, role and diversity in Lake Balaton
}

\author{
Boglárka Somogyi ${ }^{1} \mathbb{D} \cdot$ Tamás Felföldi $^{2} \cdot$ László G. Tóth $^{1} \cdot$ Gábor Bernát $^{1} \cdot$ Lajos Vörös $^{1}$
}

Received: 12 February 2020 / Accepted: 20 July 2020 / Published online: 31 July 2020

(c) The Author(s) 2020

\begin{abstract}
Occurrence of the smallest phototrophic microorganisms (photoautotrophic picoplankton, APP) in Lake Balaton was discovered in the early 1980s. This triggered a series of systematic studies on APP and resulted in the setting of a unique long-term picoplankton dataset. In this review, we intend to summarize the obtained results and to give a new insight on APP ecology and diversity in Lake Balaton. According to the results, APP dynamics depends on trophic state, temperature, nutrient, and light availability, as well as grazing pressure. APP abundance in Lake Balaton decreased to a low level $\left(1-2 \times 10^{5} \mathrm{cells}^{-1}\right)$ as a consequence of decreasing nutrient supply (oligotrophication) during the past more than two decades, and followed a characteristic seasonal dynamics with higher abundance values from spring to autumn than in winter. Concomitantly, however, the APP contribution to both phytoplankton biomass and primary production increased (up to 70\% and 40-50\%, respectively) during oligotrophication. Regarding annual pattern, picocyanobacteria are dominant from spring to autumn, while in winter, picoeukaryotes are the most abundant, most likely due to the different light and temperature optima of these groups. Within picocyanobacteria, single cells and microcolonies were both observed with mid-summer dominance of the latter which correlated well with the density of cladocerans. Community-level chromatic adaptation (i.e., dominance of phycoerythrin- or phycocyanin-rich forms) of planktonic picocyanobacteria was also found as a function of underwater light quality. Sequence analysis studies of APP in Lake Balaton revealed that both picocyanobacteria and picoeukaryotes represent a diverse and dynamic community consisting several freshwater genotypes (picocyanobacteria: Synechococcus, Cyanobium; picoeukaryotes: Choricystis, Stichococcus, Mychonastes, Nannochloris, and Nannochloropsis).
\end{abstract}

Keywords Picocyanobacteria $\cdot$ Picoeukaryotes $\cdot$ Abundance $\cdot$ Contribution $\cdot$ Primary production $\cdot$ Diversity

\section{First years: discovery of photoautotrophic picoplankton in Lake Balaton}

Photoautotrophic picoplankton' (APP)—smallest photosynthetic organisms in the size range of $0.2-2$ or $3 \mu \mathrm{m}-$ is a major fraction of the biomass of primary producers in many aquatic ecosystems, particularly in oligotrophic lakes

Electronic supplementary material The online version of this article (https://doi.org/10.1007/s42977-020-00030-8) contains supplementary material, which is available to authorized users.

Boglárka Somogyi

somogyi.boglarka@okologia.mta.hu

1 Centre for Ecological Research, Balaton Limnological Institute, Klebelsberg Kunó u. 3, Tihany 8237, Hungary

2 Department of Microbiology, ELTE Eötvös Loránd University, Pázmány Péter stny. 1/C, Budapest 1117, Hungary and oceans (Platt et al. 1983; Stockner and Antia 1986). Its global incidence was discovered in the late 1970s and early 1980s in several parts of the world, such as in Hungary (Johnson and Sieburth 1979; Waterbury et al. 1979; Vörös 1987-1988; Vörös 1991; Vörös et al. 1991). In Lake Balaton, the abundance of APP was found higher by two orders of magnitude than that of nano- and microphytoplankton, which revealed that the dominant fraction of the phytoplankton community had been neglected previously (Vörös 1987-1988). This led to a paradigm shift and a series of thorough studies on picoplankton in Lake Balaton (Table S1).

Altogether, three types of picoalgal cells were found: yellow fluorescent, phycoerythrin-rich; red fluorescent, phycocyanin-rich picocyanobacteria; and red fluorescent, picoeukaryotic algae.

Abundance of picocyanobacteria (CyAPP) usually shows a bimodal pattern with abundance maxima in spring and 
autumn and with lower abundances in summer when phytoplankton is dominated by filamentous $\mathrm{N}_{2}$-fixing cyanobacteria (Vörös 1991; Mózes et al. 2006). Picoeukaryotes (EuAPP) are present form autumn to spring and their biomass in winter is comparable to that of CyAPP in summer (Mózes et al. 2006; Vörös et al. 2009; Somogyi et al. 2016). Several studies have been performed to investigate the occurrence, role and diversity of APP in Lake Balaton and here we intend to summarize the main findings of those investigations. First, we provide a brief description on the physical and chemical environment in Lake Balaton, which largely determines the dynamics of APP.

\section{Physical and chemical environment in Lake Balaton}

Lake Balaton is the largest lake in Central Europe with a surface area of $596 \mathrm{~km}^{2}$ and a mean depth of $3.2 \mathrm{~m}$. The dominant ions in lake water are $\mathrm{Ca}^{2+}, \mathrm{Mg}^{2+}$, and $\mathrm{HCO}_{3}{ }^{-}$; whose concentration also primarily determines the observed high conductivity (650-1050 $\mu \mathrm{S} \mathrm{cm}^{-1}$ ) and $\mathrm{pH}(7.5-9.5)$ values (Table 1, Herodek 1988). Water temperature of Lake Balaton ranges from 0 to $29^{\circ} \mathrm{C}$ with an annual average of $15^{\circ} \mathrm{C}$ (Table 1 ). In winter, the lake is usually covered by ice for $42 \pm 27$ days, but years without ice cover can also occur (Vörös et al. 2009) with increasing probability. There is a characteristic depth and trophic gradient along the longitudinal axis of the lake, which latter results in a higher algal biomass concentration in the western parts of the lake as compared to the eastern one (Felföldi et al. 2011a; Vörös et al. 2009). The trophic gradient has been formed by the fact that River Zala, carrying approximately half of the water and nutrient supply of the lake (Herodek 1988) enters the westernmost point of the lake. Moreover, the depth and trophic gradient causes and coincides with significantly higher inorganic turbidity (total suspended solid, TSS) and colored dissolved organic matter (CDOM) concentration in the western parts of the lake as compared to the eastern one, which, in turn, results in different water transparencies (Table 1). As a consequence, the vertical light attenuation coefficient is higher in the western (ranges from 0.54 to $6.01 \mathrm{~m}^{-1}$, annual mean: $2.1 \mathrm{~m}^{-1}$ ) as compared to the eastern basin $\left(0.35-4.87 \mathrm{~m}^{-1}\right.$, annual mean: $\left.1.3 \mathrm{~m}^{-1}\right)$ (Table 1$)$. Besides the decrease in the light penetration from the east to the west, the spectral composition of the underwater light is concomitantly also changes (Fig. S1). Selective light absorption of the dissolved, yellowish-brownish (humic) substances (which are a major portion of CDOM) and phytoplankton (which has the highest absorption in the blue region) together causes a 'redshift' of the available light, i.e., orange/red light dominance in the western basin, which light climate significantly differs from the green light dominated eastern basin (Fig. S1; Kirk 1994; Vörös et al. 1998; Balogh et al. 2000; Wetzel and Likens 2001; Kürthy et al. 2012).

The lake underwent a strong eutrophication during the 1970s-1990s: The external phosphorus load of the lake, supplied mainly by River Zala (see above), increased largely which led to a huge biomass increase of filamentous nitrogen-fixing (diazotrophic) cyanobacteria (Herodek 1979; Vörös and Nagy Göde 1993; Padisák and Szabó 1997). This highly eutrophic period was
Table 1 Physical and chemical characteristics of Lake Balaton as well as picoplankton abundance and composition between 2003 and 2018 (Re-analysis of data from Mózes et al. 2006; Vörös et al. 2009; Somogyi et al. 2016, 2017, expanded with unpublished results)

\begin{tabular}{|c|c|c|c|c|c|c|}
\hline & \multicolumn{3}{|c|}{ Western basin } & \multicolumn{3}{|c|}{ Eastern basin } \\
\hline & Min & Max & Average & Min & Max & Average \\
\hline WT $\left({ }^{\circ} \mathrm{C}\right)$ & 0 & 29 & 15 & 0 & 29 & 15 \\
\hline $\mathrm{pH}$ & 7.48 & 9.37 & 8.47 & 7.90 & 9.48 & 8.55 \\
\hline $\mathrm{EC}\left(\mu \mathrm{S} \mathrm{cm}{ }^{-1}\right)$ & 647 & 855 & 749 & 698 & 1050 & 805 \\
\hline $\mathrm{CDOM}\left(\mathrm{mg} \mathrm{Pt} \mathrm{L}{ }^{-1}\right)$ & 6.50 & 45.94 & 17.17 & 0.63 & 11.54 & 4.44 \\
\hline $\operatorname{TSS}\left(\mathrm{mg} \mathrm{L}^{-1}\right)$ & 1.88 & 72.04 & 22.19 & 1.86 & 60.50 & 14.39 \\
\hline$K_{\mathrm{dPAR}}\left(\mathrm{m}^{-1}\right)$ & 0.54 & 6.01 & 2.10 & 0.35 & 4.97 & 1.31 \\
\hline $\operatorname{Chl}\left(\mu \mathrm{g} \mathrm{L}^{-1}\right)$ & 1.89 & 61.13 & 14.24 & 0.85 & 20.73 & 5.16 \\
\hline PE CyAPP abundance $\left(10^{3}\right.$ cells $\left.\mathrm{mL}^{-1}\right)$ & 0 & 454 & 61 & 0 & 711 & 155 \\
\hline CyAPP abundance $\left(10^{3}\right.$ cells $\left.\mathrm{mL}^{-1}\right)$ & 2 & 956 & 234 & 0 & 773 & 197 \\
\hline col CyAPP abundance $\left(10^{3}\right.$ cells $\left.\mathrm{mL}^{-1}\right)$ & 0 & 374 & 49 & 0 & 576 & 42 \\
\hline EuAPP abundance $\left(10^{3}\right.$ cells $\left.\mathrm{mL}^{-1}\right)$ & 0 & 376 & 25 & 0 & 121 & 9 \\
\hline CyAPP biomass $\left(\mu \mathrm{g} \mathrm{L}^{-1}\right)$ & 1 & 501 & 123 & 0 & 405 & 103 \\
\hline EuAPP biomass $\left(\mu \mathrm{g} \mathrm{L}^{-1}\right)$ & 0 & 746 & 52 & 0 & 244 & 19 \\
\hline
\end{tabular}

$W T$ water temperature; EC electrical conductivity; CDOM colored dissolved organic matter; TSS total suspended solid; $K_{d P A R}$ vertical attenuation coefficient of photosynthetically active radiation (PAR, 400$700 \mathrm{~nm}$ ); $C h l$ Chlorophyll $a$ concentration; $P E C y A P P$ phycoerithrin-rich picocyanobacteria; $C y A P P$ picocyanobacteria; col CyAPP colonial forms of picocyanobacteria; $E u A P P$ picoeukaryotes 
characterized by peak chlorophyll $a(\mathrm{Chl})$ concentration of up to $200-260 \mu \mathrm{g} \mathrm{L}^{-1}$ in the western basin, where it was lasted until mid-1990s (Fig. 1). In the eastern basin, the eutrophication began later and had a lower magnitude with peak chlorophyll $a$ concentrations of $30-90 \mu \mathrm{g} \mathrm{L}-1$ (Fig. 1). By the period of 2013-2018, the lake returned to its meso-eutrophic character with summer chlorophyll $a$ maxima of 30-40 $\mu \mathrm{g} \mathrm{L}^{-1}$ and $5-10 \mu \mathrm{g} \mathrm{L}^{-1}$ in the western and eastern basins, respectively (Fig. 1). Similarly to the pattern of APP abundance (see above), the overall density of phytoplankton biomass also often shows a bimodal annual pattern with a lower spring peak, attributed to diatoms, and a higher summer peak, due to filamentous diazotrophic cyanobacteria and/or planktonic dinoflagellates. This seasonality is usually much more prominent in the western basin as compared to the eastern one. In winter, phytoplankton is usually dominated by EuAPP, small

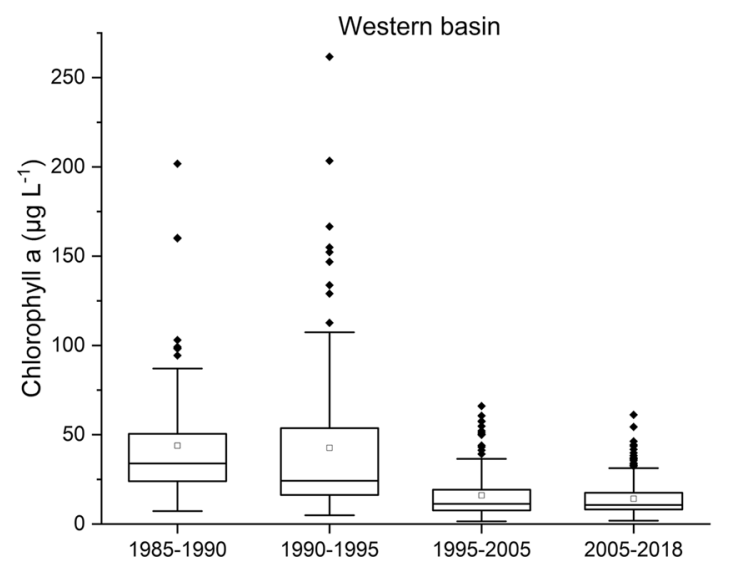

Fig. 1 Chlorophyll $a$ concentration in Lake Balaton between 1985 and 2018. (Re-analysis of data from Vörös and Nagy Göde 1993; Padisák and Szabó 1997; Vörös et al. 2009; Somogyi et al. 2017, completed with unpublished results). The plotted rectangles represent flagellates and green algae (Vörös et al. 2009; Dokulil et al. 2014; Somogyi et al. 2016; Bullerjahn et al. 2019).

\section{Abundance of APP in Lake Balaton}

The occurrence and dynamics of APP in aquatic ecosystems is controlled by both bottom-up and top-down processes (Callieri 2008; Raven et al. 2005 and references therein). For this reason, their abundance and biomass density varies in a wide range among different water types. In Lake Balaton, APP abundance and biomass density have been changing considerably both along the longitudinal axis of the lake and over the years due to variations in trophic level. Highest abundance values were observed during the highly eutrophic period in the western basin (Fig. 2). In parallel with the oligotrophication, the APP abundance decreased continuously

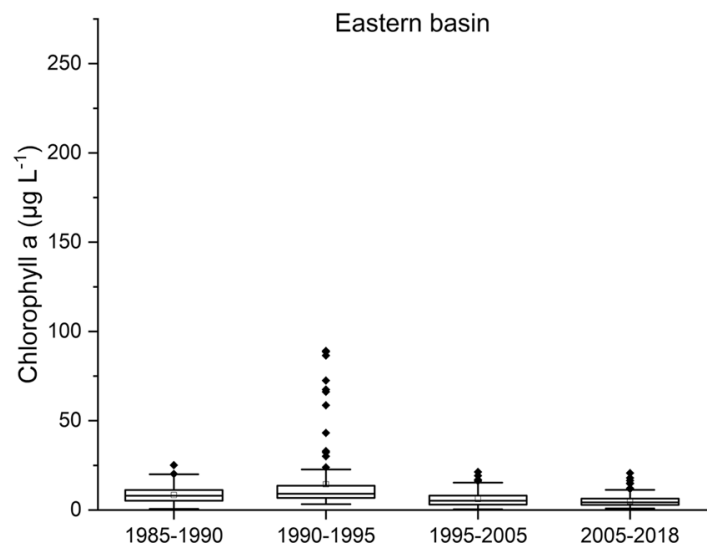

the 25th to 75th percentiles of individual measurements while the lines across the rectangles represents the median. Outliers are marked with black diamonds and mean values with squares
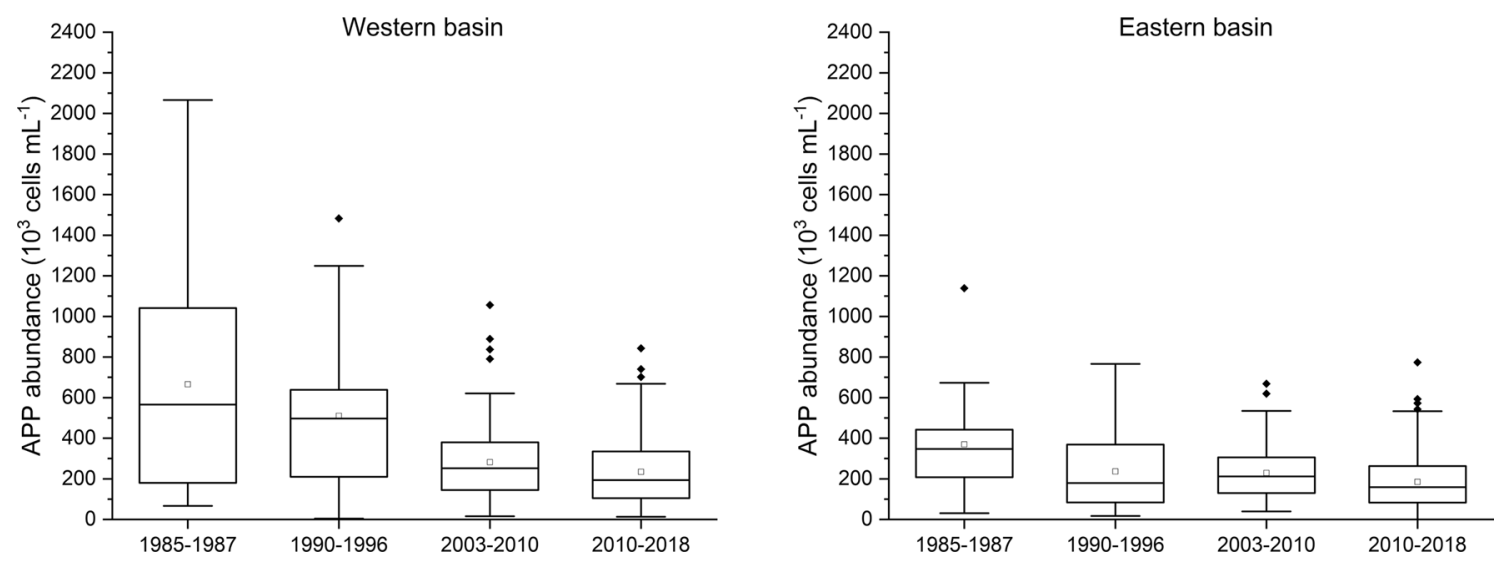

Fig. 2 Picoplankton (APP) abundance in Lake Balaton (Re-analysis of data from Vörös 1987-1988; Vörös et al. 1991, 2009; Mózes et al. 2006; Somogyi et al. 2017, completed with unpublished results). Marking as in Fig. 1 
during the subsequent period in both basins. By the period of 2010-2018, the APP abundance reduced approximately to one-third in the western basin and to approximately half in the Eastern basin as compared to that of in the 1985-1987 period (Fig. 2, Table 1).

The decrease in APP abundance with decreasing nutrient supply is a well-documented phenomenon. Its usual values ranges from $10^{2}$ to $10^{4}$ cells $\mathrm{mL}^{-1}$ in oligotrophic waters, while much higher values $\left(10^{4}-10^{6}\right.$ cells $\left.\mathrm{mL}^{-1}\right)$ was observed in eutrophic systems (Stockner and Antia 1986; Burns and Stockner 1991; Stockner and Shortreed 1991; Weisse 1993; Szelag-Wasielewska 1997). Both temporal (long-term) and spatial changes in APP abundance of Lake Balaton fits well with other results and emphasize the fundamental role of nutrient supply on APP dynamics. Besides long-term changes, as stated above, APP follows also a characteristic seasonal dynamics in Lake Balaton with higher abundance values from spring to autumn as compared to winter season (Fig. S2). The only exception to trend is when the nanoplankton fraction in the summer period is dominated by filamentous diazotrophic cyanobacteria. In summer, filamentous $\mathrm{N}_{2}$-fixing cyanobacteria can outcompete other taxonomic groups including CyAPP and EuAPP, suggesting a possible nitrogen limitation of phytoplankton in Lake Balaton (Présing et al. 2001; Vörös et al. 2009).

\section{APP contribution to phytoplankton biomass in Lake Balaton}

APP contributes significantly (up to 70\%) to phytoplankton biomass in Lake Balaton. However, this contribution follows an opposite trend than that of the abundance: It increases from the west to the east along the longitudinal axis (and parallel with decreasing trophic level) of the lake (Fig. 3). The reason of this paradox is the better nutrient supply of the western part, which affects not only the picoplankton fraction but also the nano- and microplankton. During warm periods, filamentous diazotrophic cyanobacteria seems to have a competitive advantage over CyAPP. Hence, the most likely explanation for low summer contribution of CyAPP observed in many freshwater lakes is that they are nitrogen limited (Vörös et al. 2009). In marine environments, CyAPP were shown to fix atmospheric nitrogen (Rippka et al. 1979), but in freshwaters it has not been detected yet (Postius and Böger 1998; Présing et al. 2001). During the highly eutrophic 1985-1996 period, APP mean contribution was about $7 \%$ (ranging from 0.2 to $24 \%$ ) and $13 \%$ (ranging from 1.5 to $40 \%$ ) in the western and eastern basin, respectively (Fig. 3). In parallel with the subsequent oligotrophication, this contribution increased significantly: to $14 \%$ (ranging between 0 and $73 \%$ ) and to $19 \%$ (ranging between 0 and 70\%) in the western and eastern basin, respectively (Fig. 3). This clearly shows that APP contribution in Lake Balaton largely depends on the actual trophic state and increases with decreasing phytoplankton biomass (Fig. S3). This is in good agreement with previous findings in other aquatic ecosystems (Stockner and Antia 1986; Stockner 1991; Callieri and Stockner 2002; Szelag-Wasielewska 1997).

The above discussed observations were confirmed by the quantitative regression models of Bell and Kalff (2001), which well describes the relationship between AAP contribution and total phytoplankton biomass (expressed as chlorophyll $a$ concentration) in both freshwater and marine ecosystems. The slope and intercept of such empirical relationship for Lake Balaton (log APP\% $=1.71-0.83 \log [\mathrm{Chl}]$; Fig. S3) were somewhat different from the one determined by Bell and Kalff (2001) for freshwater environments (i.e., $\log$ APP $\%=1.56-0.53 \log [\mathrm{Chl}])$. This difference, however, could arise from system morphometry, i.e., the freshwater environments studied by Bell and Kalff (2001) were mainly deep lakes with much lower inorganic turbidity than Lake
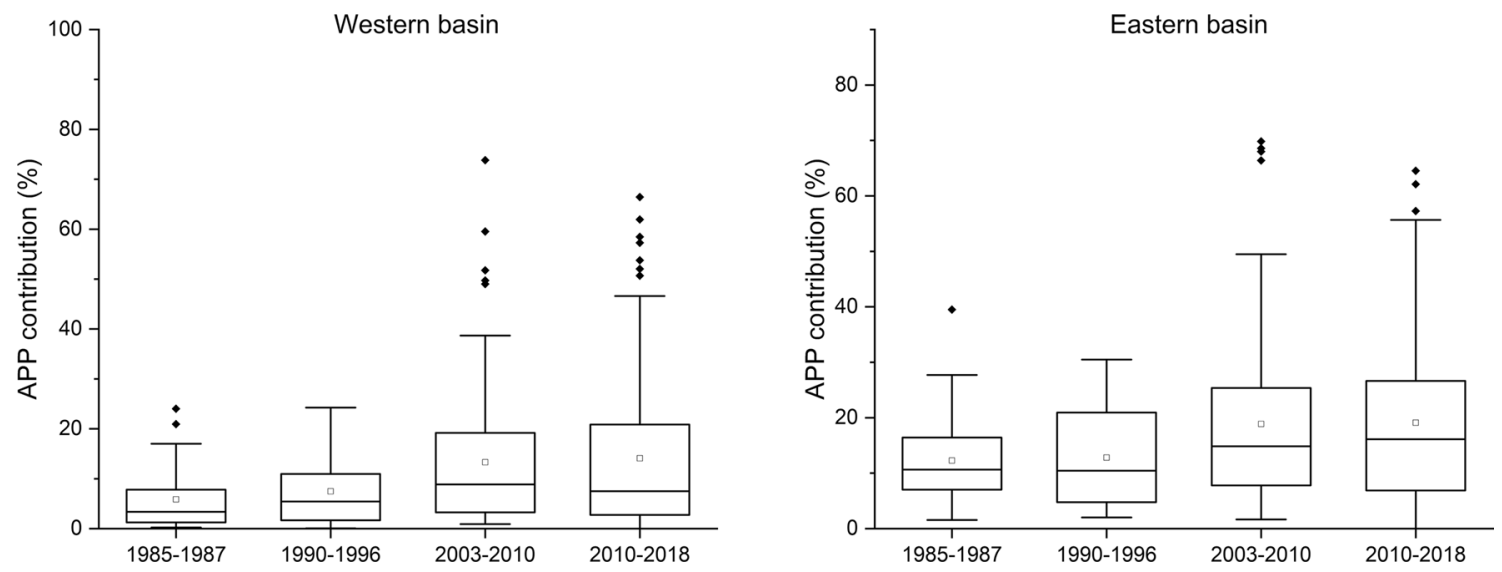

Fig. 3 Picoplankton (APP) contribution to total phytoplankton biomass in Lake Balaton (Re-analysis of data from Vörös 1987-1988; Vörös et al. 1991, 2009; Mózes et al. 2006; Somogyi et al. 2017, completed with unpublished results). Marking as in Fig. 1 
Balaton. According to our previous findings, inorganic turbidity has a significant influence on APP contribution, resulting in higher values as compared to other freshwater lakes with the same total phytoplankton biomass (Somogyi et al. 2017). This higher contribution in turbid waters might be a consequence of lower underwater light intensities and/ or reduced grazing pressure (Somogyi et al. 2017).

\section{Primary production of APP in Lake Balaton}

The contribution of APP to total phytoplankton primary production can be as high as or even exceed their biomass contribution, particularly in oligotrophic environments. Global estimates indicate that these microorganisms provide $39 \%$ of the planktonic primary production in the world's ocean: APP dominates phytoplankton biomass and production in nutrient-poor, warm $\left(>26^{\circ} \mathrm{C}\right)$ waters, but it represents only a minor fraction in nutrient-rich and cold $\left(<3{ }^{\circ} \mathrm{C}\right)$ waters (Agawin et al. 2000). Despite the fact that the APP contribution could be as high as in marine waters, much less information is available for freshwater lakes (Bell and Kalff 2001). Primary production of the picoplankton in Lake Balaton, was determined in 1986, in 2005, in 2009 and additionally in winter of 2009-2014 (Vörös 1991; Somogyi and Vörös 2006; Somogyi et al. 2016). In general, summer rates were usually higher than those in spring and autumn (with the exception of a formation of a filamentous cyanobacterial bloom in the western basin), and the winter rates were considerably lower (Somogyi et al. 2016).

During the highly eutrophic 1985-1996 period, the contribution of APP to primary production varied between 43 and $56 \%$ in the less productive eastern basin and between 1 and $57 \%$ in the western basin (Vörös 1991). In the western basin, a strong seasonal trend was also observed with a minimum APP contribution of $1 \%$ during a summer bloom of filamentous diazotrophic nitrogen-fixing cyanobacteria. During the next two decades, the summer contribution of APP in primary production increased to $23-32 \%$ in this basin. In contrast, the more oligotrophic eastern basin, such contribution was constantly high, ranging from 24 to 54\% (Somogyi and Vörös 2006; Somogyi et al. 2016). Thus, similarly to the contribution of APP to phytoplankton biomass, a strong increasing trend of APP contribution to primary production was also found with decreasing total phytoplankton biomass (Fig. S4). In winter the basindependent difference in APP contribution to primary production was abolished: It ranged between 16 and $41 \%$ in the western basin and between 13 and $46 \%$ in the eastern basin (Somogyi et al. 2016). Nevertheless, these values do not differ much from summer one, suggesting that trophic state has higher impact on APP contribution to primary production than seasonality per se, in good agreement with literature data on aquatic ecosystems (Stockner 1991; Bell and Kalff 2001; Callieri 2008).

\section{Morphotypes (single cells vs. colony forming) of planktonic picocyanobacteria in Lake Balaton}

In aquatic environments, CyAPP exist either as single cells with different morphologies (coccoid, rods, etc.) or form colonies (Stockner et al. 2000). Such microcolonies comprise a few to $>50$ individual cells (Callieri 2008 and references therein). In Lake Balaton, microcolonies of both phycoerythrin-rich and phycocyanin-rich CyAPP were found (Vörös et al. 1991; Mózes et al. 2006; Felföldi et al. 2011a): Colonial forms are dominant in mid-summer, while from autumn to early summer, mainly single cells are present (Fig. S5). Several studies suggest that colonies could be more resistant against zooplankton grazing than individual cells (Stockner et al. 2000; Crosbie et al. 2003; Callieri et al. 2016). Microcolony formation, favoured by the formation of 'spinae' on the cell surface, thus, might be a defense strategy against grazing (Komárková 2002; Jezberová and Komárková 2007; Callieri et al. 2016). Microcolonies are also surrounded by a mucilaginous polysaccharide sheet, which, besides increasing the size of the colony, could provide additional protection (Pernthaler 2005). Microcolony formation of CyAPP under grazing pressure was also confirmed by laboratory experiments (Komárková and Šimek 2003; Callieri et al. 2016). Interestingly, predation pressure provokes strain-selective responses of CyAPP, possibly because of different cell characteristics (cellular size; ability to synthetize exopolysaccharides; Callieri et al. 2016). Yet, it should be noted that although colony formation can prevent grazing by small-sized grazers (e.g., nanoflagellates, ciliates, small rotifers), microcolonies might be grazed more efficiently by larger-sized zooplankton (e.g., cladocerans, copepods) than single cells (Pernthaler and Amann 2005; Callieri et al. 2016). In Lake Balaton, abundance of colonial CyAPP shows a tight positive correlation with the abundance of Cladocera (Fig. 4, Fig. S6). Enclosure experiments also showed that cladoceran grazing can effectively control picoplankton growth in Lake Balaton; however, in that study, colonial forms were not distinguished from single cells (Vörös et al. 1991). 


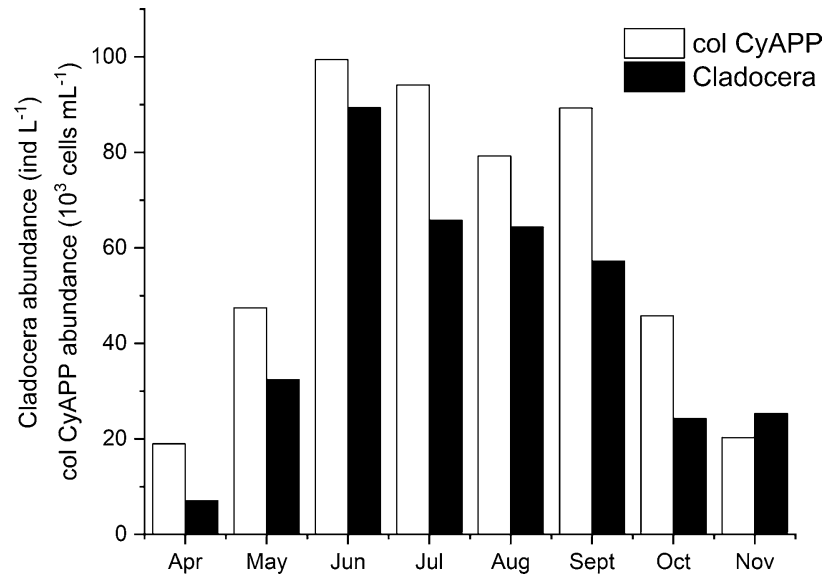

Fig. 4 Multiannual monthly averages of colonial picocyanobacteria (col CyAPP) and Cladocera between 2005 and 2015 (Re-analysis of data from Vörös et al. 2009 and Somogyi et al. 2017, completed with unpublished results)

\section{Community-level chromatic adaptation of planktonic picocyanobacteria in Lake Balaton}

CyAPP contains either phycoerythrin or phycocyanin (PE and $\mathrm{PC}$, respectively) as major light harvesting phycobiliproteins (Callieri 2008, 2017 and references therein). In Lake Balaton, both PE-rich and PC-rich CyAPP are present, however, their distribution changes largely along the longitudinal axis of the lake (Vörös 1991; Vörös et al. 1998, 2009; Mózes 2008; Mózes et al. 2006; Felföldi et al. 2011a). In the western basin, PC-rich cyanobacteria predominate, constituting about $75 \%$ of the total CyAPP. In contrast, PE-rich CyAPP are dominant in the eastern basin, where their mean contribution is about $80 \%$ (Table 1, Fig. 5). The abundance ratio of
PE/PC-rich CyAPP decreases sharply with increasing phytoplankton biomass: under $\sim 12 \mu \mathrm{g} \mathrm{L}^{-1}$ chlorophyll $a$ concentration PE-rich forms prevail, while above that threshold, PC-rich forms dominate (Fig. S7). Similar trends were found in various other aquatic ecosystems (Pick and Agbeti 1991; Stockner 1991; Callieri 2008). Picocyanobacterial pigment composition reflects the underwater light environment: The "redshift" of the available light in turbid environments (e.g., as shown for the western basin of Lake Balaton in Fig. S1) provides selective advantage for those cyanobacteria, which preferentially absorb orange-red light $(\sim 625 \mathrm{~nm})$ due to their high PC content. In contrast, PE-rich CyAPP, which effectively absorb green light $(\sim 560 \mathrm{~nm})$, prevail in clear lakes and oceans (as well as in the eastern basin of Lake Balaton), where the underwater light is dominated green color (Fig. S1; Calieri et al. 1996; Vörös et al. 1998; Camacho et al. 2003, Stomp et al. 2004, 2007; Katano et al. 2008; Haverkamp et al. 2009; Frenette et al. 2012). Laboratory experiments demonstrated that using mixed cultures, PErich and PC-rich CyAPP predominate under growing green and orange/red light, respectively. However, when they are grown together under white light, they can coexist, absorbing different parts of the light spectrum (Calieri et al. 1996; Stomp et al. 2004; 2007a).

\section{Diversity of planktonic picocyanobacteria in Lake Balaton}

Due to the lack of distinguishing morphological features, members of APP could taxonomically be identified by DNA sequence analysis. For prokaryotes, the most widely used marker is the 16S rRNA gene (Felföldi et al. 2011b; Callieri et al. 2013; Callieri 2017), which is also present in
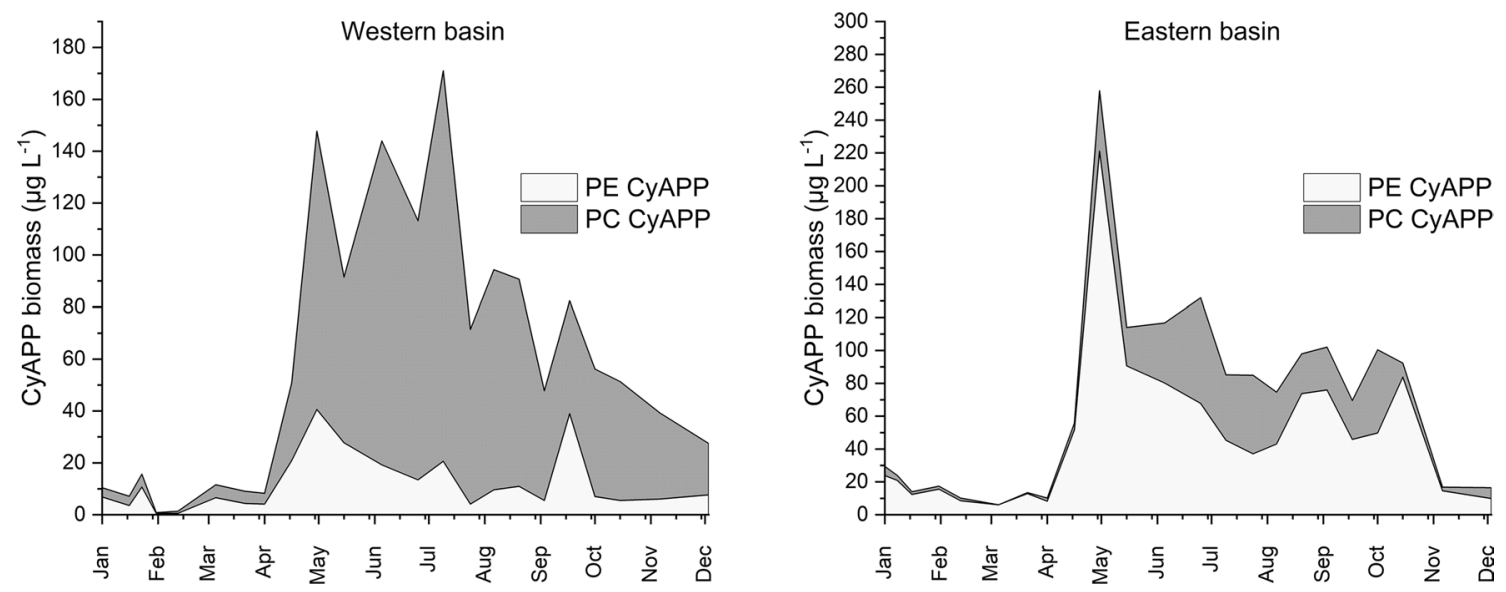

Fig. 5 Biomass of phycoerithrin-rich (PE) and phycocyanin-rich (PC) picocyanobacteria in Lake Balaton in 2011 (Re-analysis of data from Kürthy et al. 2012) 
chloroplasts, therefore, could also be used for the identification of eukaryotic algae (e.g., Fuller et al. 2006).

Various PC- and PE-rich picocyanobacterial strains have previously been isolated from Lake Balaton, which belong to Group A (Cyanobium gracile cluster) and Group B (subalpine cluster I), respectively, of the non-marine lineages of the picophytoplankton clade sensu Urbach et al. (1998) (Fig. 6; Felföldi et al. 2011a, b). These two groups are among the most common genotypes of freshwater picocyanobacteria distributed worldwide in diverse types of lakes and ponds (e.g., Crosbie et al. 2003; Callieri et al. 2013; Huang et al. 2014; Vasileva et al. 2017).

Phylogenetic analysis of uncultured sequences revealed the occurrence of several other picocyanobacterial groups (e.g., PD1, CB4, LB03) in Lake Balaton (Fig. 7). The relative abundance of the detected genotypes was basin-dependent, pronounced seasonal changes were also observed.
According to the data, their abundance was primarily determined by temperature and availability of nitrogen forms (Felföldi et al. 2011a), however, other abiotic and biotic factors such as orthophosphate concentration, viral lysis, etc. (Becker et al. 2007; Mühling et al. 2005) may have also significant impact on it. In summary, planktonic picocyanobacteria in Lake Balaton represent a diverse and dynamic community, consisting of various genotypes of freshwater Synechococcus and Cyanobium.

\section{APP in wintertime: dominance of picoeukaryotes in Lake Balaton}

Occurrence of picoeukaryotic algae in Lake Balaton was first time observed in winter 2003 (Mózes and Vörös 2004; Mózes et al. 2006). From that time, APP studies have been
Fig. 6 Maximum likelihood phylogenetic trees of picoalgal strains and the most abundant uncultured planktonic genotypes from Lake Balaton based on $16 \mathrm{~S}$ rRNA gene sequences. Reanalysis of sequence data from Felföldi et al. (2011a), Somogyi et al. (2016) and Borsodi et al. (2017). Uncultured genotypes were retrieved from samples collected in February 2003, October 2005 and June 2013. The cyanobacterial phylogenetic tree is based on 584, the plastid tree is based on 568 nucleotide positions, and in both cases the Kimura 2-parameter substitution model was applied. For methodological details of phylogenetic tree construction, see Kalwasińska et al. (2017). GenBank and Sequence Read Archive codes are given in parentheses. Bootstrap values higher than 50 are shown at the nodes. Lake Balaton strains are highlighted with purple and uncultured genotypes with light blue letters. Phycoerythrin-rich picocyanobacteria are marked with red, phycocyanin-rich picocyanobacteria with green circles, while eukaryotic algal species having cells smaller than $3 \mu \mathrm{m}$ are marked with brown triangles. Cluster designation of picocyanobacteria follows the nomenclature of Crosbie et al. (2003), Chen et al. (2006) and Ivanikova et al. (2007). Abbreviation: mpc marine picophytoplankton clade

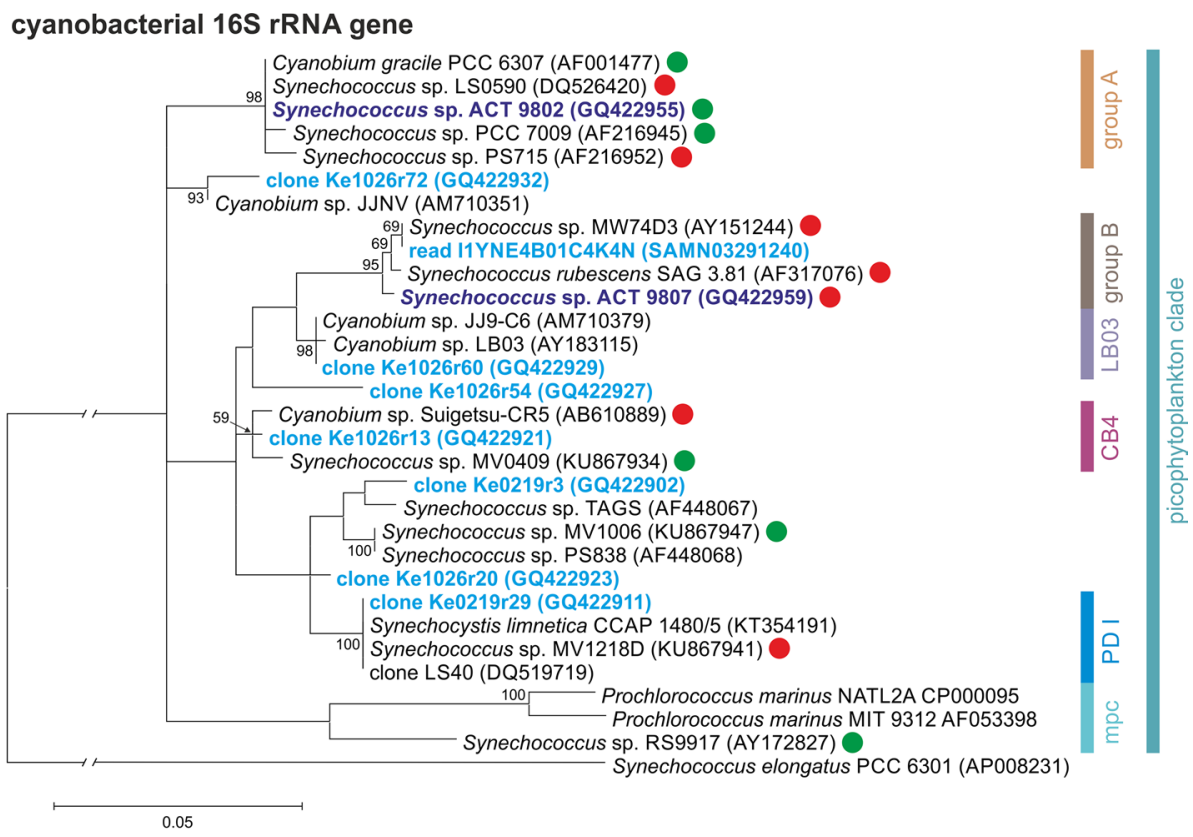

plastid 16S rRNA gene

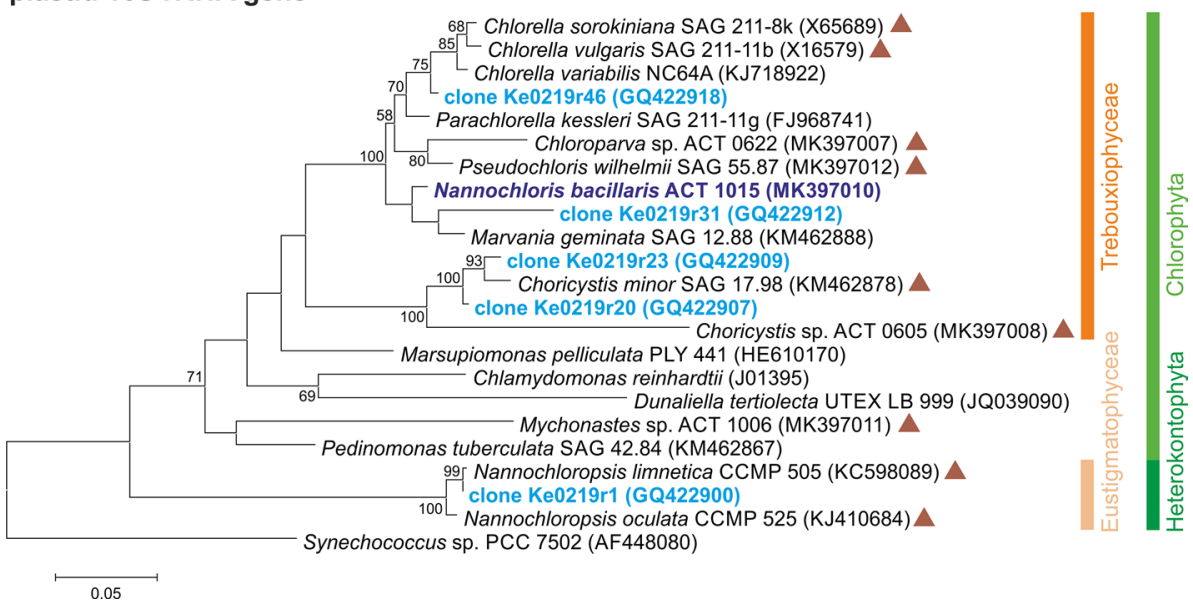




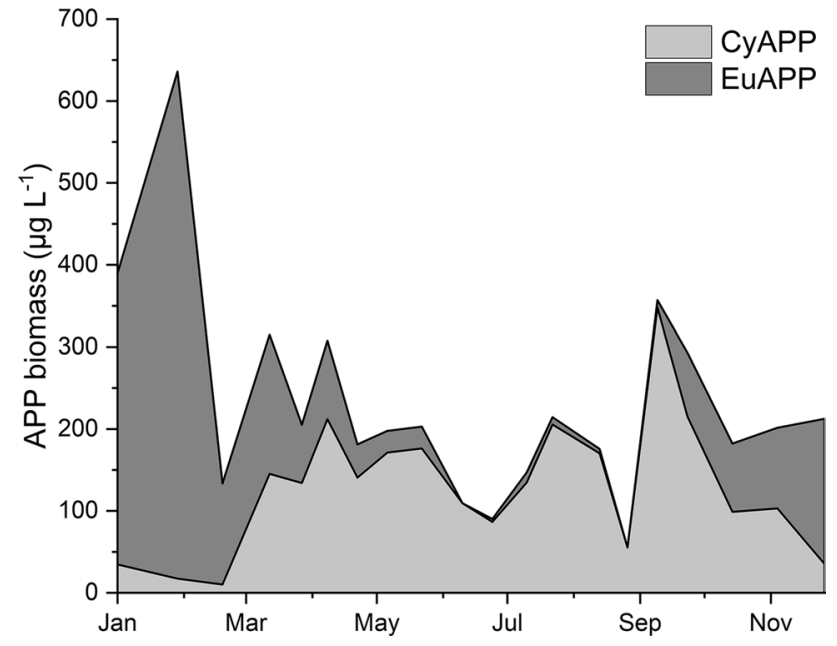

Fig. 7 Biomass of picocyanobacteria (CyAPP) and picoeukaryotes (EuAPP) in the western Basin of Lake Balaton in 2012 (Re-analysis of data from Somogyi et al. 2016)

extended to the winter season, which revealed a characteristic seasonal dynamics of APP (Vörös et al. 2009; Somogyi et al. 2012, 2016). In regards of CyAPP, their minimum biomass is usually found in winter, follows by an increase in spring and maxima are recorded in summer or in the beginning of autumn (Fig. 7; Vörös et al. 2009). In both basins, positive relationship was described between temperature and CyAPP abundance (Vörös et al. 2009), which is a general phenomenon in both marine and freshwater environments (Waterbury et al. 1986; Malinsky-Rushansky et al. 1995; Stockner et al. 2000; Callieri and Stockner 2002).

The annual pattern for picoeukaryotes (EuAPP) shows an opposite trend, i.e., starts to grow in autumn and attained its maxima in late winter or early spring, irrespective of the presence or absence of ice cover (Fig. 7; Vörös et al. 2009). In summer, EuAPP is almost undetectable (Fig. 7). The abundance of picoeukaryotes is much higher in the eutrophic western basin than in the mesotrophic eastern one (Table 1). The highest EuAPP abundances are found below $8{ }^{\circ} \mathrm{C}$, and they became negligible above $15^{\circ} \mathrm{C}$ (Fig. S8). The contribution of CyAPP and picoeukaryotes to the total picoplankton biomass also depends on water temperature: EuAPP contribution is high above $10^{\circ} \mathrm{C}$ (Fig. S8). Thus, the seasonal pattern of EuAPP is similar in the shallow Lake Balaton to larger deep lakes, with a single population peak in spring or early summer (Stockner et al. 2000).

EuAPP and CyAPP cells are considerably different in terms of phylogeny, structure, and physiology. The winter and summer predominance of EuAPP and CyAPP, respectively, reflect the different light- and temperature optima of these microorganisms. EuAPP has competitive advantage over CyAPP under conditions characterized by low light and temperature, as was also observed at harsh polar environments (Pálffy et al. 2014; Metfies et al. 2016). In general, EuAPP cells have a lower light demands as compared to CyAPP cells, although the latter group also includes low-light-adapted microorganisms (Callieri 2008). In the Pacific Ocean, for instance, CyAPP contribute more to the picoplankton productivity in the lower regions (1-7\% of the surface irradiance) of the euphotic zone than in the well-lit region ( $>15 \%$ of the surface irradiance) (Rii et al. 2016). In Lake Balaton, EuAPP-dominated winter communities have much lower light demands, than the CyAPP-dominated summer communities (Somogyi et al. 2016). Determination of the photosynthetic activities of CyAPP and EuAPP strains confirmed the crucial role of light and temperature in the seasonal dynamics of picophytoplankton: In agreement with field data, ca. $15{ }^{\circ} \mathrm{C}$ appeared to be the key temperature below which the maximum photosynthetic rate $\left(P_{\max }\right)$ and light utilization parameter $(\alpha)$ of the EuAPP strains exceeded that of the CyAPP strains (Somogyi et al. 2009).

In summary, key factors controlling the abundance of picoeukaryotes differ from those ones controlling CyAPP (Vörös et al. 2009). Importantly, during the cold-water period, when both water temperature and irradiance are appropriate for picoeukaryotes, the concentrations of available nitrogen and phosphorus are the highest in Lake Balaton (Présing et al. 2001; Vörös et al. 2009). On the other hand, in summer, when both water temperature and irradiance are optimal for CyAPP, nitrogen limitation can occur (Vörös et al. 2009).

\section{Diversity of eukaryotic picoalgae in Lake Balaton}

Although the bacterial 16S rRNA gene is present in the chloroplast (see above), due to the limited number of available reference sequences, taxonomic identification of eukaryotic algae is usually carried out by the sequence analysis of the 18S rRNA gene, which latter provides limited resolution at distinguishing closely related species (Krienitz and Bock 2012).

The taxonomic composition of the picoeukaryotic phytoplankton community in Lake Balaton is similar to those in other freshwater lakes in the temperate zone. Isolated strains from Lake Balaton all belong to Chlorophyta and were taxonomically identified as Choricystis sp., Stichococcus bacillaris, Nannochloris bacillaris, and Mychonastes sp. (Somogyi et al. 2016), which corresponds well with previous findings showing green algal dominance in freshwater picoplankton. Community-level DNA-based studies of the phytoplankton community in Lake Balaton also suggests the dominance of chlorophytes within eukaryotic APP (Felföldi et al. 2011a, Fig. 7). The majority of the isolates were identified as members of the genus Choricystis (Somogyi et al. 
2016), which is widely distributed in freshwater lakes in Europe, Asia and North-America (Belykh et al. 2000; Fawley et al. 2004; Hepperle and Krienitz 2001; Hepperle and Schlegel 2002). Members of the Mychonastes clade, which were also isolated from Lake Balaton, are also reported from various lakes worldwide (Hepperle and Krienitz 2001; Hepperle and Schlegel 2002; Krienitz et al. 1999; Fawley et al. 2004; Hanagata et al. 1999; Shi et al. 2019).

Interestingly, the heterokontophyte pico-sized green alga Nannochloropsis was also detected in Lake Balaton (Fig. 7). Members of this genus were identified from different freshwater and saline aquatic ecosystems (Krienitz et al. 2000; Suda et al. 2002; Karlov et al. 2017), and the diverse isolation source of sequences having $>99 \%$ nucleotide similarity to the clone retrieved from Lake Balaton (based on a GenBank search; jelly-like biofilm, Lake Baikal; sediment, West Lake Bonney, Antarctica; Nam Co Lake, China; winter hospital shower water, USA; Wanigawa River, Japan; freshwater, Baffin Island, Canada) suggests the high adaptation potential and widespread distribution of this uncommon member of APP.

Taken together the results of cultivation and cultureindependent studies, it seems that Choricystis is the most abundant genus in Lake Balaton within eukaryotic APP, while the occurrence of members of genera Stichococcus, Mychonastes, Nannochloris, Nannochloropsis (and also some unidentified taxonomic groups) are also proven (Fig. 7). Apparently, many of the above-mentioned genera (e.g., Choricystis, Mychonastes and Stichococcus) isolated from Lake Balaton may contain oil droplets (Vörös et al. 2009; Wu et al. 2015; Selvarajan et al. 2016; Chen et al. 2017), which suggests their role as a valuable food source for heterotrophic flagellates and mesozooplankton on one hand and potential use of them in future biotechnological applications.

\section{Conclusions for future biology}

Picophytoplankton forms the base of the food web in most aquatic ecosystems. Essential role of APP in Lake Balaton was also clearly demonstrated, based on the analysis of a long-term phytoplankton dataset, covering the period from mid-1980s to the present. The overview provided by this review may help to understand better the role and diversity of APP and to identify the main drivers of their dynamics. Future studies should focus on the impact of global changes, i.e., how climate change will presumably affect their physiology, genetic diversity, as well as population dynamics, and, more generally, their exact ecological role in Lake Balaton. Addressing these questions is not simple: It has just been demonstrated that APP can answer positively (with elevated biomass values) to ocean warming (Flombaum et al. 2020).
As a result, warmer conditions can lead to elevated phytoplankton biomass in oceanic regions that are already dominated by APP, which contradicts to previous findings on worldwide declining phytoplankton biomass. This, together with niche partitioning of APP communities according to light and temperature gradients, will, expectedly lead to an altered genetic diversity.

Exploring the factors affecting APP dynamics is of major importance, as APP is the main primary producer in most of marine and freshwater environments and it is the key element of all aquatic food webs. In case of Lake Balaton, grazing is suggested to further studies influencing APP dynamics as bottom-up control is widely studied. Feeding experiments with natural lake water communities and algal isolates may provide novel data on the effect of grazing on the phytoplankton community with special attention to APP. Metagenomics of the gut content may serve further information on the feeding behavior of various zooplankton taxa. Allelopathic defense mechanisms of APP against grazer attack have also been poorly studied.

Another intriguing, yet understudied issue is the role of picoalgae on surface habitats, i.e., on sediment surface, lakeshore underwater surfaces, ice cover in winter, etc. in Lake Balaton. Moreover, to understand better the remarkable seasonal dynamics of APP in Lake Balaton, exploring the dormant forms of the APP cells will also be of interest.

Acknowledgements Open access funding provided by ELKH Centre for Ecological Research. We are grateful to Balázs Németh and Tímea Szabó for technical assistance as well as Géza Dobos for sample collection. This work was financially supported by Hungarian Scientific Research Fund (Grant No. K116275 to T.F. and K128950 to G.B. and B.S.). T.F. was supported by the János Bolyai Research Scholarship of the Hungarian Academy of Sciences (Grant No. BO/00837/20/8).

\section{Compliance with ethical standards}

Conflict of interest The authors declare that they have no conflict of interest.

Open Access This article is licensed under a Creative Commons Attribution 4.0 International License, which permits use, sharing, adaptation, distribution and reproduction in any medium or format, as long as you give appropriate credit to the original author(s) and the source, provide a link to the Creative Commons licence, and indicate if changes were made. The images or other third party material in this article are included in the article's Creative Commons licence, unless indicated otherwise in a credit line to the material. If material is not included in the article's Creative Commons licence and your intended use is not permitted by statutory regulation or exceeds the permitted use, you will need to obtain permission directly from the copyright holder. To view a copy of this licence, visit http://creativecommons.org/licenses/by/4.0/. 


\section{References}

Agawin NSR, Duarte CM, Agusti S (2000) Nutrient and temperature control of the contribution of picoplankton to phytoplankton biomass and production. Limnol Oceanogr 45:1891

Balogh KV, Koncz E, Vörös L (2000) An empirical model describing the contribution of colour, algae and particles to the light climate of shallow lakes. Verh Internat Verein Limnol 27:2678-2681

Becker S, Richl P, Ernst A (2007) Seasonal and habitat-related distribution pattern of Synechocccus genotypes in Lake Constance. FEMS Microbiol Ecol 62:64-77

Bell T, Kalff J (2001) The contribution of picophytoplankton in marine and freshwater systems of different trophic status and depth. Limnol Oceanogr 46:1243-1248

Belykh OI, Semanova EA, Kuznedelov KD, Zaika EI, Guselnikova NE (2000) An eukaryotic alga from picoplankton of Lake Baikal: morphology, ultrastructure and rDNA sequence data. Hydrobiologia 435:83-90

Borsodi AK, Szabó A, Krett G, Felföldi T, Specziár A, Boros G (2017) Gut content microbiota of introduced bigheaded carps (Hypophthalmichthys spp.) inhabiting the largest shallow lake in Central Europe. Microbiol Res 195:40-50

Bullerjahn GS, McKay RML, Bernát G, Prásil O, Vörös L, Pálffy K, Tugyi N, Somogyi B (2019) Community dynamics and function of algae and bacteria during winter in central European great lakes. J Great Lakes Res. https://doi.org/10.1016/j. jglr.2019.07.002

Burns CW, Stockner JG (1991) Picoplankton in 6 New-Zealand Lakes-abundance in relation to season and trophic state. Int Rev Ges Hydrobiol 76:523-536

Calieri C, Amicucci E, Bertoni R, Vörös L (1996) Fluorometric characterization of two picocyanobacteria strains from lakes of different underwater light quality. Int Rev Ges Hydrobiol 81:13-23

Callieri C (2008) Picophytoplankton in freshwater ecosystems: the importance of small-sized phototrophs. Freshw Rev 1:1-28

Callieri C (2017) Synechococcus plasticity under environmental changes. FEMS Microbiol Lett. https://doi.org/10.1093/femsle/ fnx 229

Callieri C, Stockner J (2002) Picocyanobacteria success in oligotrophic lakes: fact or fiction? J Limnol 59:72-76

Callieri C, Coci M, Corno G, Macek M, Modenutti B, Balseiro E, Bertoni R (2013) Phylogenetic diversity of nonmarine picocyanobacteria. FEMS Microbiol Ecol 85:293-301

Callieri C, Amalfitano S, Corno G, Bertoni R (2016) Grazing-induced Synechococcus microcolony formation: experimental insights from two freshwater phylotypes. FEMS Microbiol Ecol. https:// doi.org/10.1093/femsec/fiw154

Camacho A, Miracle MR, Vicente E (2003) Which factors determine the abundance and distribution of picocyanobacteria in inland waters? A comparison among different types of lakes and ponds. Arch Hydrobiol 157:321-338

Chen F, Wang K, Kan J, Suzuki M, Wommack KE (2006) Diverse and unique picocyanobacteria in Chesapeake Bay, revealed by 16S-23S rRNA Internal Transcribed Spacer sequences. Appl Environ Microbiol 72:2239-2243

Chen Y, Li X-Y, Sun Z, Zhou Z-G (2017) Isolation and identification of Choricystis minor Fott and mass cultivation for oil production. Algal Res 25:142-148

Crosbie ND, Teubner K, Weisse T (2003) Flow-cytometric mapping provides novel insights into the seasonal and vertical distributions of freshwater autotrophic picoplankton. Aquat Microb Ecol 33:53-66

Dokulil MT, Herzig A, Somogyi B, Vörös L, Donabaum K, May L, Nöges T (2014) Winter conditions in six European shallow lakes: a comparative synopsis. Est J Ecol 63:111-129
Fawley MW, Fawley KP, Buchheim MA (2004) Molecular diversity among communities of freshwater microchlorophytes. Microb Ecol 48:489-499

Felföldi T, Duleba M, Somogyi B, Vajna B, Nikolausz M, Présing M, Márialigeti K, Vörös L (2011a) Diversity and seasonal dynamics of the photoautotrophic picoplankton in Lake Balaton (Hungary). Aquat Microb Ecol 63:273-287

Felföldi T, Somogyi B, Márialigeti K, Vörös L (2011b) Notes on the biogeography of non-marine planktonic picocyanobacteria: reevaluating novelty. J Plankton Res 33:1622-1626

Flombaum P, Wang W-L, Primeau FW, Martiny AC (2020) Global picophytoplankton niche partitioning predicts overall positive response to ocean warming. Nat Geosci 13:116-120

Frenette JJ, Massicotte P, Lapierre JF (2012) Colourful niches of phytoplankton shaped by the spatial connectivity in a large river ecosystem: a riverscape perspective. PLoS ONE 7:e35891

Fuller NJ, Campbell C, Allen DJ, Pitt FD, Le Gall F, Vaulot D, Scanlan DJ (2006) Analysis of photosynthetic picoeukaryote diversity at open ocean sites in the Arabian Sea using a PCR biased towards marine algal plastids. Aquat Microb Ecol 43:79-93

Hanagata N, Malinsky-Rushansky N, Dubinsky Z (1999) Eukaryotic picoplankton, Mychonastes homosphaera (Chlorophyceae, Chlorophyta) in Lake Kinneret, Israel. Phycol Res 47:263-269

Haverkamp THA, Schouten D, Doeleman M, Wollenzien U, Huisman J, Stal LJ (2009) Colorful microdiversity of Synechococcus strains (picocyanobacteria) isolated from the Baltic Sea. ISME J 3:397-408

Hepperle D, Krienitz L (2001) Systematics and ecology of chlorophyte picoplankton in German inland waters along a nutrient gradient. Int Rev Hydrobiol 86:269-284

Hepperle D, Schlegel I (2002) Molecular diversity of eukaryotic picoalgae from three lakes in Switzerland. Int Rev Ges Hydrobiol 87:1-10

Herodek S (1979) Eutrofizálódás, a Balatont fenyegetô közvetlen veszély. MTA Biol Oszt Közl 22:323-336

Herodek S (1988) Limnology of Lake Balaton. In: Misley K (ed) Lake Balaton research and management. Nexus, Budapest, pp 9-28

Huang S, Liu Y, Hu A, Liu X, Chen F, Yao T, Jiao N (2014) Genetic diversity of picocyanobacteria in Tibetan lakes: assessing the endemic and universal distributions. Appl Environ Microbiol 80:7640-7650

Ivanikova NV, Popels LC, McKay ML, Bullerjahn GS (2007) Lake Superior supports novel clusters of cyanobacterial picoplankton. Appl Environ Microbiol 73:4055-4065

Jezberová J, Komárková J (2007) Morphological transformation in a freshwater Cyanobium sp. induced by grazers. Environ Microbiol 9:1858-1862

Johnson PW, Sieburth J McN (1979) Chroococcoid cyanobacteria in the sea: a ubiquitous and diverse phototrophic biomass. Limnol Oceanogr 24:928-935

Kalwasińska A, Felföldi T, Szabó A, Deja-Sikora E, Kosobucki P, Walczak M (2017) Microbial communities associated with the anthropogenic, highly alkaline environment of a saline soda lime, Poland. Antonie van Leeuwenhoek 110:945-962

Karlov DS, Marie D, Sumbatyan DA, Chuvochina MS, Kulichevskaya IS, Alekhina IA, Bulat SA (2017) Microbial communities within the water column of freshwater Lake Radok, East Antarctica: predominant $16 \mathrm{~S}$ rDNA phylotypes and bacterial cultures. Polar Biol 40:823-836

Katano T, Nakano S, Mitamura O, Yoshida H, Azumi H, Matsuura Y, Tanaka Y, Maezono H, Satoh Y, Satoh T, Suigiyama Y, Watanabe Y, Mimura T, Akagashi Y, Machida H, Drucker VV, Tikhonova I, Belykh O, Fialkov VA, Han MS, Kang SH, Sugiyama M (2008) abundance and pigment type composition of picocyanobacteria in Barguzin Bay, Lake Baikal. Limnology 9:105-114 
Kirk JTO (1994) Light and photosynthesis in aquatic ecosystems, 2nd edn. University Press, Cambridge, p 401

Komárková J (2002) Cyanobacterial picoplankton and its colonial formations in two eutrophic canyon reservoirs (Czech Republic). Arch Hydrobiol 154:605-623

Komárková J, Šimek K (2003) Unicellular and colonial formations of picoplanktic cyanobacteria under different environmental conditions and predation pressure. Arch Hydrobiol Suppl Algol Stud 109:327-340

Krienitz L, Bock C (2012) Present state of the systematics of planktonic coccoid green algae of inland waters. Hydrobiologia 698:295-326

Krienitz L, Takeda H, Hepperle D (1999) Ultrastructure, cell wall composition, and phylogenetic position of Pseudodictyosphaerium jurisii (Chlorococcales, Chlorophyta) including a comparison with other picoplanktonic green algae. Phycologia 38:100-107

Krienitz L, Hepperle D, Stich H-B, Weiler W (2000) Nannochloropsis limnetica (Eustigmatophyceae), a new species of picoplankton from freshwater. Phycologia 39:219-227

Kürthy A, Somogyi B, Németh B, Vörös L (2012) A víz alatti fény spektrális összetételének hatása sekély tavak pikoplanktonjára. Hidrológiai Közlöny 92:49-52

Malinsky-Rushansky N, Berman T, Dubinsky Z (1995) Seasonal dynamics of picophytoplankton in Lake Kinneret, Israel. Freshw Biol 34:241-254

Metfies K, Appen WJ, Kilias E, Nicolaus A, Nöthig EM (2016) Biogeography and photosynthetic biomass of Arctic marine pico-eukaryotes during summer of the record sea ice minimum 2012. PLoS ONE 11:e0148512. https://doi.org/10.1371/journal.pone.0148512

Mózes, A. (2008) Pikoplankton a trofikus grádiens mentén. Doktori $(\mathrm{PhD})$ értekezés, ELTE, Biológia Doktori Iskola, Kísérletes Növénybiológia Doktori Program

Mózes A, Vörös L (2004) Különleges pikoplankton együttesek a befagyott Balatonban. Hidrológiai Közlöny 84:180-182

Mózes A, Présing M, Vörös L (2006) Seasonal dynamics of picocyanobacteria and picoeukaryotes in a large shallow lake (Lake Balaton, Hungary). Int Rev Ges Hydrobiol 91:38-50

Mühling M, Fuller NJ, Millard A, Somerfield PJ et al (2005) Genetic diversity of marine Synechococcus and co-occurring cyanophage communities: evidence for viral control. Environ Microbiol 7:499-508

Padisák J, Szabó I (1997) Botanikai kutatások a Balatonon: alacsonyés magasabbrendû növények. In: Salánki J, Nemcsók J (eds) A Balatonkutatás eredményei 1981-1996. MTA Veszprémi Területi Bizottsága és a Miniszterelnöki Hivatal Balatoni Titkársága, Veszprém, pp 97-135

Pálffy K, Felföldi T, Mentes A, Horváth H, Márialigeti K, Boros E, Vörös L, Somogyi B (2014) Unique picoeukaryotic algal community under multiple environmental stress conditions in a shallow, alkaline pan. Extremophiles 18:111-119

Pernthaler J (2005) Predation on prokaryotes in the water column and its ecological implications. Nat Rev Microbiol 3:537-546

Pernthaler J, Amann R (2005) Fate of heterotrophic microbes in pelagic habitats: focus on populations. Microbiol Mol Biol R 69:440-461

Pick FR, Agbeti M (1991) The seasonal dynamics and composition of photosynthetic picoplankton communities in temperate lakes in Ontario, Canada. Int Rev Ges Hydrobiol 76:565-580

Platt T, Subba Rao DV, Irwin B (1983) Photosynthesis of picoplankton in the oligotrophic ocean. Nature 301:702-704

Postius C, Böger P (1998) Different interactions of phycoerythrin- and phycocyanin-rich Synechococcus spp. with diazottrophic bacteria from the picoplankton of Lake Constance. Arch Hydrobiol 141:181-194

Présing M, Herodek S, Preston T, Vörös L (2001) Nitrogen uptake and the importance of internal nitrogen loading in Lake Balaton. Freshw Biol 46:125-139
Raven JA, Finkel ZV, Irwin AJ (2005) Picophytoplankton: bottomup and top-down controls on ecology and evolution. Vie Milieu 55:209-215

Rii YM, Duhamel S, Bidigare RR, Karl DM, Repeta DJ, Church MJ (2016) Diversity and productivity of photosynthetic picoeukaryotes in biogeochemically distinct regions of the South East Pacific Ocean. Limnol Oceanogr 61:806-824

Rippka R, Deruelles J, Waterbury JB, Herdman M, Stainer RY (1979) Generic assignments, strain histories and properties of pure cultures of cyanobacteria. J Gen Microbiol 111:1-61

Selvarajan R, Felföldi T, Sanniyasi E, Tekere M (2016) Assessing the potential of some freshwater and saline microalgae as biodiesel feedstock. J Biobased Mater Bioenergy 10:50-62

Shi X, Li S, Fan F, Zhang M, Yang Z, Yang Y (2019) Mychonastes dominates the photosynthetic picoeukaryotes in Lake Poyang, a river-connected lake. FEMS Microbiol Ecol. https://doi. org/10.1093/femsec/fiy211

Somogyi B, Vörös L (2006) A pikoplankton fotoszintézisének karakterisztikái sekély tavakban. Hidrológiai Közlöny 86:110-112

Somogyi B, Felföldi T, Vanyovszki J, Ágyi Á, Márialigeti K, Vörös L (2009) Winter bloom of picoeukaryotes in Hungarian shallow turbid soda pans and the role of light and temperature. Aquat Ecol 43:735-744

Somogyi B, Felföldi T, Márialigeti K, Vörös L (2012) Sekély tavaink téli eukarióta pikoalgái. Hidrológiai Közlöny 92:61-63

Somogyi B, Felföldi T, Balogh KV, Boros E, Pálffy K, Vörös L (2016) The role and composition of winter picoeukaryotic assemblages in shallow Central European great lakes. J Great Lakes Res 42:1420-1431

Somogyi B, Pálffy K, Balogh KV, Botta-Dukát Z, Vörös L (2017) Unusual behaviour of phototrophic picoplankton in turbid waters. PLoS ONE 12:3

Stockner JG (1991) Autotrophic picoplankton in freshwater ecosystems: the view from summit. Int Rev Ges Hydrobiol 76:483-492

Stockner JG, Antia NJ (1986) Algal picoplankton frommarine and freshwater: a multidisciplinary perspective. Can J Fish Aquat Sci 43:2472-2503

Stockner JG, Shortreed KS (1991) Autotrophic Picoplankton-community composition, abundance and distribution across a gradient of oligotrophic British-Columbia and Yukon-Territory Lakes. Int Rev Ges Hydrobiol 76:581-601

Stockner JG, Callieri C, Cronberg G (2000) Picoplankton and other non-bloom forming cyanobacteria in lakes. In: Whitton B, Potts AM (eds) The ecology of cyanobacteria. Kluwer, New York, pp 195-231

Stomp M, Huisman J, Jongh F, Veraart AJ, Gerla D, Rijkeboer M, Ibelings BW, Wollenzien UIA, Stal LJ (2004) Adaptive divergence in pigment composition promotes phytoplankton biodiversity. Nature 432:104-106

Stomp M, Huisman J, Vörös L, Pick FR, Laamanen M, Haverkamp T, Stal LJ (2007) Colourful coexistence of red and green picocyanobacteria in lakes and seas. Ecol Lett 10:290-298

Suda S, Atsumi M, Miyashita H (2002) Taxonomic characterization of a marine Nannochloropsis species, N. oceanica sp. nov. (Eustigmatophyceae). Phycologia 41:273-279

Szelag-Wasielewska E (1997) Picoplankton and other size groups of phytoplankton in various shallow lakes. Hydrobiologia 342(343):79-85

Urbach E, Scanlan DJ, Distel L, Waterbury JB, Chisholm SW (1998) Rapid diversification of marine picophytoplankton with dissimilar light-harvesting structures inferred from sequences of Prochlorococcus and Synechococcus (Cyanobacteria). J Mol Evol 46:188-201

Vasileva A, Skopina M, Averina S, Gavrilova O, Ivanikova N, Pinevich A (2017) Metagenomic analysis in Lake Onego (Russia) Synechococcus cyanobacteria. J Great Lakes Res 43:43-54 
Vörös L (1987-1988) Bakteriális méretű fotoautotrófikus szervezetek néhány sekély tóban. Botanikai Közlemények 74-75:141-151

Vörös L (1991) Importance of picoplankton in Hungarian shallow lakes. Verh Internat Verein Limnol 24:984-988

Vörös L, Nagy Göde P (1993) Long term changes of phytoplankton in Lake Balaton (Hungary). Verhandlungen des Internationalen Verein Limnologie 25:682-686

Vörös L, Gulyás P, Németh J (1991) Occurrence, dynamics and production of picoplankton in Hungarian shallow lakes. Int Rev Ges Hydrobiol 76:617-629

Vörös L, Callieri C, Balogh KV, Bertoni R (1998) Freshwater picocyanobacteria along a trophic gradient and light quality range. Hydrobiologia 369(370):117-125

Vörös L, Mózes A, Somogyi B (2009) A five-year study of autotrophic winter picoplankton in Lake Balaton, Hungary. Aquat Ecol 43:727-734
Waterbury JB, Watson SW, Guillard RR, Brand LE (1979) Widespread occurrence of a unicellular, marine, planktonic cyanobacterium. Nature 277:293-294

Waterbury JB, Watson SW, Valois FW, Franks DG (1986) Biological and ecological characterization of the marine unicellular cyanobacterium Synechococcus. Can Bull Fish Aquat Sci 214:71-120

Weisse T (1993) Dynamics of autotrophic picoplankton in marine and freshwater ecosystems. Adv Microbial Ecol 13:327-370

Wetzel RG, Likens GE (2001) Limnological analyses, 3rd edn. Springer, New York

Wu L, Xu L, Hu C (2015) Screening and characterization of oleaginous microalgal species from Northern Xinjiang. J Microbiol Biotechnol 25:910-917 